\title{
Prenatal early diagnosis of dacryocystocele, a case report and review of literature
}

\author{
Dakriyosistoselin prenatal erken tanısı, vaka sunumu ve literatür taraması
}

\author{
Banu Bingöl, Alin Başgül, Nilgün Güdücü, Herman İşci, İlkkan Dünder \\ Department of Obstetrics and Gynecology, Faculty of Medicine, Bilim University, Istanbul, Turkey
}

\section{Abstract}

Dacryocystocele (mucocele, amniocele) is a relatively rare variant of nasolacrimal duct obstruction which refers to the cystic dilatation of lacrimal pathway above and below the lacrimal sac. It is a benign pathology and can be treated successfully after birth, but its prenatal detection is important, because it may be seen in numerous syndromes and may serve as their marker. Bilateral cysts have the possibility for intranasal extension and an obstruction to the nasal passages may result in neonatal respiratory distress requiring surgical intervention Unilateral cases are important for the differential diagnosis with serious facial abnormalities. We present a case of early prenatal detection of a 28 year-old G: 1 P: 0 pregnant woman with bilateral dacryocystocele. She presented a live, normally developed singleton fetus on sonographic examination at 12,16 and 22 weeks. At $25^{\text {th }}$ weeks, we diagnosed a hypoechogenic mass, that was situated inferomedially to the eyes in the fetal face with 2 and 3-D ultrasound. A 3850-g live female infant was delivered by Cesarean section due to breech presentation at 39 weeks following preterm rupture of membranes. We report the case with intranasal components studied during fetal life by 2 and 3-D ultrasound and magnetic resonance (MR) imaging.

(J Turkish-German Gynecol Assoc 2011; 12: 259-62)

Key words: Dacryocystocele, mucocele, amniocele, magnetic resonance imaging, nasolacrimal duct cyst

Received: 24 August, 2010

Accepted: 24 September, 2010
Özet

Dakriyosistosel (mukosel, amniosel), lakrimal drenaj sisteminin distalde ve proksimalde oklüze olarak, mukus ve amniotik sıvının birikmesi ile kistik dilatasyonudur. Dakriyosistosel; benign bir patolojidir ve doğum sonrası başarılı bir şekilde tedavi edilebilir. Dakriyosistoselin konjenital anomaliler ve sendromlarla birlikteliği, prenatal tanısının önemini göstermektedir. Bilateral dakriyosistosel, neonatal nasal obstrüksiyona neden olabileceği ve resüsitasyon gerektirebileceği için doğum sırasında dikkat edilmelidir. Unilateral vakalar, bazı ciddi fasiyal anomalilerle ayrıcı tanı açısından önemlidir. Prenatal dakriyosistosel nadir görülen bir patoloji olup, literatürde prenatal tanı alan vaka sayısı son decece azdır. Bu olgu sunumunda 28 yaşında, G: 1 P: 0 bir gebede 25. haftada tespit edilen bilateral dakriyosistoselin, 2-D ve 3-D ultrasonografik ve magnetik rezonans incelemesi (MRI) görüntüleri sunulmuştur. Gebeliğin takibindeki 12., 16., 22. haftalardaki ultrasonografik incelemelerinde herhangi bir patoloji saptanmamıştır, 25. haftada fetal yüzde orbitaların inferomedialinde bilateral hipoekojen kistik yapılar tespit edilmiştir. 39. haftada membran rüptürünü takiben makat prezentasyonu nedeniyle sezaryen ile doğum gerçekleştirilmiş ve 3850 gr kız bebek doğurtulmuştur. Tedavi postnatal dönemde aralıklı lakrimal kanal masajları ile gerçekleştirilmiştir. Literatüre bakıldığında en erken tanı alan ve en küçük çapta tespit edilen olgudur.

(J Turkish-German Gynecol Assoc 2011; 12: 259-62)

Anahtar kelimeler: Dakriyosistosel, mukosel, amniosel, manyetik rezonans inceleme, nasolakrimal kanal kisti

Geliş Tarihi: 24 Ağustos 2010

Kabul Tarihi: 24 Eylül 2010

\section{Introduction}

Dacryocystocele is the occlusion of lacrimal drainage system distally and proximally during the fetal life; it dilates accumulating mucus and amniotic fluid (1). The causes of dacryocystocele include congenital deformities, trauma, primary and recurrent tumors affecting the nasolacrimal duct, idiopathic blockage of the nasolacrimal duct and iatrogenic causes including treatment of head and neck cancer in the sinonasal region $(2,3)$. Prenatal diagnosis is nevertheless important, because bilateral dacryocystocele, extending intranasally is one of the possible causes of neonatal nasal obstruction $(4,5)$. Moreover unilateral cases make the prenatal differential diagnosis of serious facial anomalies more difficult. Besides, it may be part of some syndromes, which makes the prenatal early diagnosis more important (6-8).

\section{Case Report}

A 28 year-old G:1 P:0 pregnant woman admitted to our clinic for antenatal follow up. A first trimester nuchal translucency measurement of $1.7 \mathrm{~mm}$ was associated with an adjusted risk for trisomy 21 of 1 in 730 . Normal anatomy of the fetus including face and central nervous system were demonstrated at the 22-week examination. In $25^{\text {th }}$ week, she admitted for a control and oral glucose loading test. The ultrasound examination demonstrated a breech presentation. We noticed bilateral cystic lesions measuring $0.5 \times 0.6 \mathrm{~mm}$ and $0.5 \times 0.4 \mathrm{~mm}$ inferomedial to the orbits. The facial profile seemed normal and the intraocular anatomy was also normal with synchronous movement of the eyes. The detailed examination of the brain appeared normal. The genetic sonogram revealed no evidence of any other associated abnormality. We referred

Address for Correspondence: Banu Bingöl, Burhanettin Üstünel Cad., No: 20, Üsküdar 34668 İstanbul, Turkey

Phone: +90212266 6646 e.mail: banubingol1975@yahoo.com

(C) Copyright 2011 by the Turkish-German Gynecological Education and Research Foundation - Available online at www.jtgga.org doi:10.5152/jtgga.2011.60 
the patient for a fetal magnetic resonance (MR) imaging examination. The abnormality was shown with 2D -3D ultrasound and MR as shown in Figure 1-3. A repeat scan 2 weeks later revealed the cyst volumes to be slightly increased $(0.7 \times 0.8 \mathrm{~mm}$ and $0.8 \times 0.9$ ) with no additional findings. We examined the patient every 2 weeks and followed the dimensions of the cysts and other possible abnormal findings. We diagnosed the case as bilateral dacryocystocele and the parents were counseled about the pathology. It is explained that dacryocystocele is usually an isolated pathology however rarely; it might be part of a syndrome that may not be identified antenatally. A 3850-g live female infant was delivered by Cesarean section due to breech presentation at 39 weeks following preterm rupture of membranes. The dimension of cysts at right and left sides were $1.2 \times 1.3$ and $1.1 \times 1.4$ respectively. There were no clinical signs of respiratory compromise and the infant revealed a blue swelling on the medial borders of both orbits confirming the diagnosis of dacryocystocele. Postnatally, the infant was consulted with Ophthalmology Department and the dacryocystocele was treated with gentle massage in 2 weeks. The infant seemed normal after the treatment and no further treatment was necessary. She completed 6 months of life and there is no evidence of any recurrence.

\section{Discussion}

Dacryocystocele or lacrimal duct cyst is a very rare condition caused by obstruction of the lacrimal duct, usually due to a thin membrane remaining at its distal end. Rupture of the cyst is normally spontaneous during the first month of life (9). Prenatal of congenital dacryocystocele has been described but there are a few reports in the literature, and the earliest diagnosis was made in $27^{\text {th }}$ gestational weeks (10).

The diagnosis is potentially important because bilateral cysts have the possibility for intranasal extension and an obstruction to the nasal passages may result in neonatal respiratory distress requiring surgical intervention (11). Because neonates obligate nasal breathers, the risk of acute respiratory distress in the early neonatal period should be considered and a pediatrician should be present for delivery (6).

The differential diagnosis of perinatal masses includes dacryocystocele, cystic teratomas, dermoid cysts, hemangiomas, encephalocele, nasal glioma and rhabdomyosarcoma (7). The differential diagnosis between dacryocystocele and other less benign periorbital masses is often not possible only with ultrasound, especially when the lesion is unilateral. Prenatal MR imaging better defines the location of the various components of lacrimal system dilatation and their relation to the nasal cavity. This information may provide the possible postnatal respiratory distress (12).

The lacrimal drainage system begins to develop around the $6^{\text {th }}$ week of pregnancy. As the surface ectoderm in the naso-optic fissure thickens, an epithelial cord detaches from it and buries itself between the lateral nasal and maxillary processes. Cephalic and caudal growth of this epithelial cord will give rise to the lacrimal canaliculi, sac and duct (8). Canalization of the nasolacrimal pathway begins at about 12 weeks of gestation

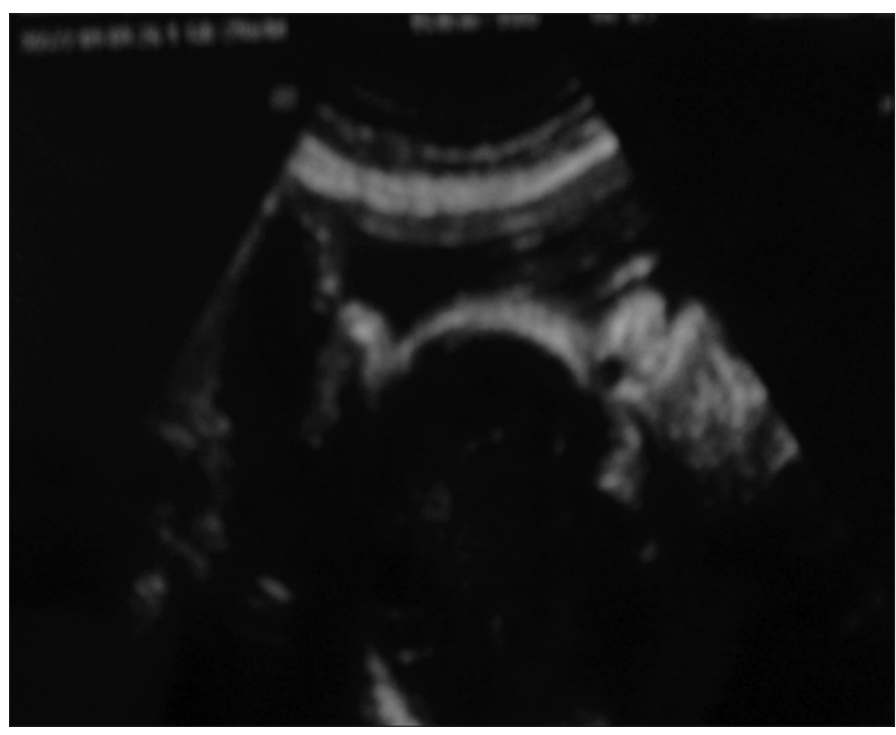

Figure 1. 2-D view of dacryosystocele

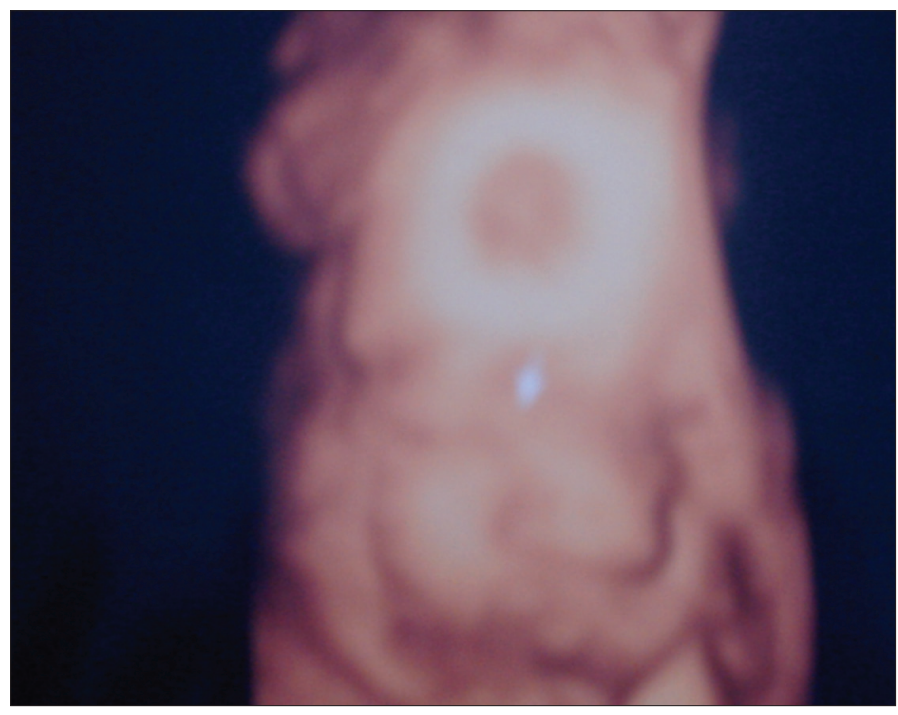

Figure 2. 3-D view of dacryosystocele

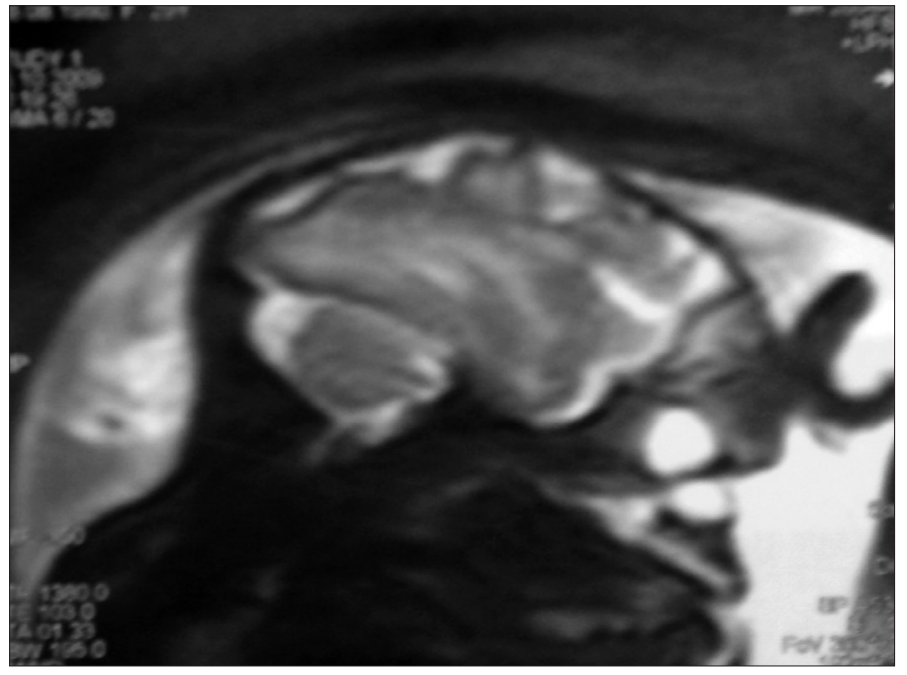

Figure 3. MRI view of dacryosystocele 
and is complete from as early as 24 weeks. However, the nasal (distal) end may perforate only at birth or even later (10). In our case, the first antenatal diagnosis was made at $25^{\text {th }}$ gestational week. To our knowledge, it is the earliest case diagnosed prenatally in the literature.

Atresia of the Hasner valve, at the distal end of the nasolacrimal duct, is the main cause of simple congenital dacryostenosis (13). Dacryocystocele is a much less common disorder, is already symptomatic at birth. In this condition, additional functional obstruction at the orbital end of the lacrimal sac is present together with the atresia of the distal end of the nasolacrimal duct. The sac fills with amniotic fluid and intrinsic mukoid secretion and becomes distended, causing the canaliculi to kink. These then act as a one-way valve, permitting fluid only to enter into the sac (14).

There are a few numbers of prenatal diagnoses of dacryocystocele reported in the literature. In two reports of Rand and Walsh, the diagnoses were made at 30-36 weeks of gestation $(15,16)$. Sharony et al. who reported the earliest diagnosis was at $27^{\text {th }}$ gestational weeks; desribed 6 cases of dacryocystocele; accompanying some syndromes and other pathologies as Canavan disease, pyelectasis, dysplastic kidney and maternal diabetes (10). Westbrook et al., reported recurrent bilateral dacryocystoceles in Wegener's granulomatosis which is defined as a chronic disease with peak onset between the ages of 20-40 years (17). The classic Wegener's triad includes; necrotizing granulomas of the upper and lower respiratory tract, vasculitis, and glomerulonephritis (18). In our case there was no other pathology neither defined on prenatal scan nor after birth. Dacryocystocele is seen as a hypoechogenic mass locating inferiomedially to the orbit that may be seen in the coronal or parasagittal plane including the nose and medial angle of the orbits. Hemangioma is cutaneous in origin and it is located in the head or neck, septated or solid (19). It is differentiated form the dacryocystocele with its typical Doppler patterns (20). A dermoid cyst has a complex appearance and hyperechogenic situated superolaterally to the globe on ultrasound with areas of calcification usually present. Anterior cephalocele is a mid-line defect accompanied by a calvarial defect and usually hydrocephalus. The other orbital masses are neurofibromatosis, lymphangioma and rhabdomyosarcoma, but these are solid in origin and extremely rare. Nasolacrimal mucocele is also very rare and difficult to be diagnosed prenatally (21).

The sonographic appearance of dacryocystocele allows the differential diagnosis of this pathology, revealing the location, size, time of appearance, echogenicity and Doppler flow characteristics (22). MRI is helpful in ruling out a potential intracranial connection (23).

The treatment of dacryocystocele is controversial (24-26). Most of the physicians have advocated conservative treatment with antibiotics and massage $(27,28)$. Lucarelli et al. reported a case of corneal ectasia associated with massage of dacryocystocele (29). In our patient, we used gentle massage and treated the pathology successfully with no complication. Some physicians have recommended early surgical intervention if there is not a rapid response to conservative therapy or recommended prompt surgical therapy $(21,23)$.
In conclusion, when the diagnosis is contemplated prenatally, it is important to be aware of the risk of acute respiratory distress in the early neonatal period especially if the pathology is bilateral (30). Besides, other possible causes of duct obstruction or cystic dilatation must be excluded. The possibility of associations with syndromes must be kept in mind and other structural abnormalities should be controlled carefully.

\section{Conflict of interest}

No conflict of interest was declared by the authors.

\section{References}

1. Ogawa GS, Gonnering RS. Congenital nasolacrimal duct obstruction. J Pediatr 1991; 119: 12-7. [CrossRef]

2. Shashy RG, Durairaj VD, Holmes JM, Hohberger GG, Thompson DM, Kasperbauer JL. Congenital dacryocystocele associated with intranasal cysts: diagnosis and management. Laryngoscope 2003; 113: 37-40. [CrossRef]

3. Bhaya M, Meehan R, Har-El G. Dacryocystocele in an adult: endoscopic management. Am J Otolaryngol 1997; 18: 131-4. [CrossRef]

4. Castillo M, Merten DF, Weissler MC. Bilateral nasolacrimal duct mucocele, a rare cause of respiratory distress: CT findings in two newborns. Am J Neuroradiol 1993; 14: 1011-3.

5. Hepler KM, Woodson GE, Kearns DB. Respiratory distress in the neonate. Sequela of a congenital dacryocystocele. Arch Otolaryngol Head Neck Surg 1995; 121: 1423-5.

6. Alper CM, Chan KH, Hill LM, Chenevey P. Antenatal diagnosis of a congenital nasolacrimal duct cyst by ultrasonography: a case report. Prenat Diagn 1994; 14: 623-6. [CrossRef]

7. Shipp TD, Bromley B, Benacerraf B. The ultrasonographic appearance and outcome for fetuses with masses distorting the fetal face. J Ultrasound Med 1995; 14: 673-8.

8. Sevel D. Development and congenital abnormalities of the nasolacrimal apparatus. J Pediatr Ophthalmol Strabismus 1981; 18: 13-9.

9. Salvetat ML, D'Ottavio G, Pensiero S, Vinciguerra A, Perissutti P. Prenatal sonographic detection of a bilateral dacryocystocele. J Pediatr Ophthalmol Strabismus 1999; 36: 295-7.

10. Sharony R, Raz J, Aviram R, Cohen I, Beyth Y, Tepper R. Prenatal diagnosis of dacryocystocele: a possible marker for syndromes Ultrasound Obstet Gynecol 1999; 14: 71-3. [CrossRef]

11. Right PD, Hubbell RN, Lawrol PP Jr. Respiratory distress associated with bilateral nasolacrimal duct cysts. Int J Pediatr Otorhinolaryngol 1993; 26: 199-203. [CrossRef]

12. Bianchini E, Zirpoli S, Righini A, Rustico M, Parazzini C, Triulzi F. Magnetic resonance imaging in prenatal diagnosis of dacryocystocele: report of 3 cases. J Comput Assist Tomogr 2004; 28: 422-7. [CrossRef]

13. Cassady JV. Developmental anatomy of nasolacrimal duct. AMA Arch Ophthalmol 1952; 47: 141-58.

14. Rand PK, Ball WS Jr, Kulwin DR. Congenital nasolacrimal mucoceles: CT evaluation. Radiology 1989; 173: 691-4.

15. Walsh G, Dubbins PA. Antenatal sonographic diagnosis of a dacryocystocele. J Clin Ultrasound 1994; 22: 457-60. [CrossRef]

16. Davis WK, Mahony BS, Carroll BA, Bowie JD. Antenatal sonographic detection of benign dacrocystoceles (lacrimal duct cysts). J Ultrasound Med 1987; 6: 461-5.

17. Westbrook BJ, Scurry WC Jr, Hudak DT, McGinn J, Stack BC Jr. Recurrent bilateral dacryocystoceles in Wegener's granulomatosis: a rhinologic perspective. Am J Otolaryngol 2006; 27: 409-12. [CrossRef]

18. Gubbels SP, Barkhuizen A, Hwang PH. Head and neck manifestations of Wegener's granulomatosis. Otolaryngol Clin North Am 2003; 36: 685-705. [CrossRef] 
19. Meizner I, Bar-Ziv J, Holcberg G, Katz M. In utero prenatal diagnosis of fetal facial tumor-hemangioma. J Clin Ultrasound 1985; 13: 435-7. [CrossRef]

20. Pennell RG, Baltarowich OH. Prenatal sonographic diagnosis of a fetal facial hemangioma. J Ultrasound Med 1986; 5: 525-8.

21. Mansour AM, Barber JC, Reinecke RD, Wang FM. Ocular choristomas. Surv Ophthalmol 1989; 33: 339-58. [CrossRef]

22. Sepulveda W, Wojakowski AB, Elias D, Otaño L, Gutierrez J. Congenital dacryocystocele: prenatal 2- and 3-dimensional sonographic findings. J Ultrasound Med 2005; 24: 225-30.

23. Brugger PC, Weber M, Prayer D. Magnetic resonance imaging of the fetal efferent lacrimal pathways. Eur Radiol 2010; 20: 1965-73. [CrossRef]

24. Harris GJ, DiClementi D. Congenital dacryocystocele. Arch Ophthalmol 1982; 100: 1763-5.
25. Schnall BM, Christian CJ. Conservative treatment of congenital dacryocele. J Pediatr Ophthalmol Strabismus 1996; 33: 219-22.

26. Paysse EA, Coats DK, Bernstein JM, Go C, de Jong AL. Management and complications of congenital dacryocele with concurrent intranasal mucocele. J AAPOS 2000; 4: 46-53. [CrossRef]

27. Levy NS. Conservative management of congenital amniotocele of the nasolacriminal sac. J Pediatr Ophthalmol Strabismus 1979; 16 : 254-6.

28. Grin TR, Mertz JS, Stass-Isern M. Congenital nasolacrimal duct cysts in dacryocystocele. Ophthalmology 1991; 98: 1238-42.

29. Lucarelli MJ, DeBry P. Corneal ectasia associated with massage of dacryocystoceles. Cornea 2002; 21: 419-20. [CrossRef]

30. Tsai YS, Huang JK. Neonatal nasal obstruction caused by bilateral dacryocystoceles. Pediatr Radiol 2006; 36: 1221. [CrossRef] 